\title{
IL1RL1 wt Allele
}

National Cancer Institute

\section{Source}

National Cancer Institute. IL1RL1 wt Allele. NCI Thesaurus. Code C106009.

Human IL1RL1 wild-type allele is located in the vicinity of $2 q 12$ and is approximately $41 \mathrm{~kb}$ in length. This allele, which encodes interleukin-1 receptor-like 1, is involved in immune response signal transduction. 